\title{
Volume, firmness and crumb characteristics of gluten-free bread based on extruded quinoa flour and lactic acid
}

\section{Características de volume, firmeza e miolo do pão sem glúten \\ à base de farinha de quinoa extrusada e ácido láctico}

\author{
Elvia Murgueytio ${ }^{1}$, Stalin Santacruz ${ }^{1,2 *}$ (1) \\ ${ }^{1}$ Universidad San Francisco de Quito, Departamento de Ingenieria de Alimentos, Quito - Ecuador \\ 2Universidad Laica Eloy Alfaro de Manabí, Facultad Ciencias Agropecuarias, Manta - Ecuador
}

*Corresponding Author: Stalin Santacruz, Universidad Laica Eloy Alfaro de Manabí, Facultad Ciencias

Agropecuarias, Via San Mateo, s/n, 130802, Manta, Manabi - Ecuador, e-mail: stalin.santacruz@gmail.com

Cite as: Murgüeytio, E., \& Santacruz, S. (2020). Volume, firmness and crumb characteristics of gluten-free bread based on extruded quinoa flour and lactic acid. Brazilian Journal of Food Technology, 23, e2019220.

https://doi.org/10.1590/1981-6723.22019

\begin{abstract}
Coeliac disease forces on the developing of gluten-free products. Gluten-free cereals may be modified by techniques like cooking-extrusion or by adding compounds like lactic acid in order to obtain mixtures with adequate viscoelastic properties for the developing of baked products. The present work studies the elaboration of gluten-free bread with extruded quinoa (Chenopodium quinoa Willd) flour and lactic acid. The influence of feeding humidity (18\% and $25 \%$ ) and temperature of extrusion $\left(60^{\circ} \mathrm{C}\right.$ and $95^{\circ} \mathrm{C}$ ) on water absorption index (WAI) and water solubility index (WSI) of extruded flours was investigated. The results showed that feeding humidity led to changes on WAI. Baking process was studied by varying the amount of lactic acid added during bread baking. The specific volume, firmness and crumb characteristics (average cell size and cell number per $\mathrm{mm}^{2}$ ) of bread were determined. A control sample based on commercial gluten-free flour and no lactic acid was used. The results showed that lactic acid content did not affect bread firmness. Bread prepared with extruded flours at $95{ }^{\circ} \mathrm{C}, 25 \%$ feeding moisture had higher firmness $(p<0.05)$ than bread prepared with other extruded flours and control sample. Low level of lactic acid $(0.2 \%)$ led to bread with high specific volume. The use of an extruded quinoa flour with low levels of lactic acid led to a gluten-free bread with a high specific volume and low firmness.
\end{abstract}

Keywords: Cooking-extrusion; Coeliac disease; Water absorption index; Water solubility index; Crumb; Chenopodium quinoa Willd.

\section{Resumo}

Doença celíaca força o desenvolvimento de produtos sem glúten. Cereais sem glúten podem ser modificados por técnicas como cozimento-extrusão ou pela adição de compostos como ácido láctico, a fim de obter misturas com propriedades viscoelásticas adequadas para o desenvolvimento de produtos assados. No presente trabalho, foi estudada a elaboração de pão sem glúten com farinha de quinoa extrusada (Chenopodium quinoa Willd) e ácido láctico, bem como a influência da umidade de alimentação (18\% e $25 \%)$ e da temperatura de extrusão $\left(60{ }^{\circ} \mathrm{C}\right.$ e $\left.95^{\circ} \mathrm{C}\right)$ no 
índice de absorção de água (WAI) e no índice de solubilidade em água (WSI) de farinhas extrusadas. Os resultados mostraram que a umidade de alimentação levou a mudanças no WAI. O processo de panificação foi estudado variando a quantidade de ácido láctico adicionada no produto. O volume específico, a firmeza e as características do miolo (tamanho médio de célula e número de células por $\mathrm{mm}^{2}$ ) de pão foram determinadas. Uma amostra controle baseada em farinha comercial sem glúten e sem ácido láctico foi utilizada. Os resultados mostraram que o teor de ácido láctico não afetou a firmeza do pão. Pão elaborado com farinhas extrusadas a $95^{\circ} \mathrm{C}$ e $25 \%$ de umidade de alimentação apresentou maior firmeza $(p<0,05)$ do que a do pão elaborado com outras farinhas extrusadas e a firmeza da amostra testemunha. Baixo nível de ácido láctico $(0,2 \%)$ levou a um pão com alto volume específico. O uso de uma farinha de quinoa extrusada com baixos níveis de ácido láctico resultou em um pão sem glúten, com alto volume específico e baixa firmeza.

Palavras-chave: Cozimento-extrusão; Doença celíaca; Índice de absorção de água; Índice de solubilidade em água; Migalhas; Chenopodium quinoa Willd.

\section{Introduction}

Coeliac disease is characterised for the body's intolerance to cereal prolamins (Bold \& Rostami, 2011). One percent of population in Europe and U.S.A., between $0.46 \%$ and $0.64 \%$ in Latin America (Parra et al., 2014) and approximately one of each 140 Ecuadorian habitants suffer from coeliac disease (Celíacos del Ecuador, 2012). Wheat and other cereals are commonly used in the food industry, being glutenin and gliadin from wheat the responsible for the developing of bread unique characteristics (volume and texture). Therefore, the elaboration of gluten-free products for people suffering from coeliac disease is a challenge that needs the utilisation of new food materials (Ahlborn et al., 2005).

In classical bread making, wheat gluten forms a three-dimensional network that retains gas bubbles during baking. However, during the elaboration of bread with starch, organic acids may be added to improve bread quality characteristics. Because starch is the only significant macromolecule in gluten-free bread (no protein or cellulose is present), a three-dimensional network may be formed between lactic acid and starch (Dufour et al., 1996). Previous studies have shown that UV radiation during starch drying together with the presence of lactic acid, led to a starch oxidation and changes on the starch dough during cooking, giving as a result an increase of bread volume (Mestres \& Rouau, 1997; Plata-Oviedo \& Camargo, 1998). Crust and crumb colours and the texture of gluten-free bread may be improved by the presence of lactic acid (Clerici et al., 2009). An acidification with a blend of acetic acid and lactic acid modulates dough rheological properties, which are relevant in gluten-free products (Villanueva et al., 2018). Acetic acid, lactic acid and citric acid were used as food additives in gluten-free bread, improving the preservative effects of the dough (Blanco et al., 2011; Rinaldi et al., 2017). Based on the previous information, it may be interesting to investigate the effect of adding lactic acid on the elaboration of gluten-free bread based on quinoa flour.

Chenopodium quinoa Willd (quinoa) is originary from the Andean region in South America. From a nutritional point of view, quinoa is similar to casein due to its high chemical score and a balance composition of essential amino acids. Quinoa is already used on the elaboration of breakfast cereals. However, despite quinoa comes from South America, few processed foods containing quinoa are available in Andean countries like Ecuador, flour mixtures containing quinoa and a cereal or leguminosae, baby food and drinks based on mixtures of cereals with quinoa, bread with a partial substitution of wheat flour. Moreover, due to its protein quality, more food products should incorporate this pseudo cereal. However, the developing of baked products based on quinoa flour requires formation of adequate viscoelastic properties of dough. Cooking-extrusion (extrusion) modifies the functional properties of flour due to gelatinisation of starch along with protein unfolding and aggregation (Gómez \& Martínez, 2016). Extrusion improves emulsifying and foaming properties of flours making them more suitable for some gluten-free products (Martínez et al., 2014a, 2014b). There are studies about the improvement of bread quality by substituting native rice flour for extruded rice flour (Martínez et al., 2013, 2014c). Acidic extruded rice flour was used to improve the quality of rice bread (Clerici et al., 2009; Clerici \& El-Dash, 2006). Defloor et al. (1991) found that a mixture of extruded starches 
and emulsifying agents improved the quality of breads prepared with a mixture of tapioca and soya. However, there are no studies on the use of extruded quinoa on the developing of gluten-free bread.

Mixtures of flours from quinoa, rice and corn (Elgeti et al., 2014); quinoa and buckwheat (Turkut et al., 2016); quinoa and amaranth (Machado et al., 2015); soya an sorghum (Susanna \& Prabhasankar, 2013) have been used in gluten-free bread formulations.

The present work studies the utilisation of extrusion as a tool to modify functional properties (water absorption and water solubility index) of quinoa flour. The use of extruded flour together with lactic acid on the elaboration of gluten-free bread was studied by measuring volume, firmness and crumb characteristics (average cell size and cell number per $\mathrm{mm}^{2}$ ) of the baked bread.

\section{Material and methods}

\subsection{Flour extrusion}

Quinoa grains were purchased from Sumak Life Company (Riobamba, Ecuador). Extrusion was performed with an extruder (Brabender Do-Corder DCE 330, C. W. Brabender Instruments, Germany) with the following characteristics: a single screw, three heating chambers and a compression ratio of 1:1. A completely random design with a factorial arrangement of $2^{2}$ and measurements in triplicate were used for the elaboration of extruded quinoa flour. The factors were the temperature on the third heating chamber $\left(60{ }^{\circ} \mathrm{C}\right.$ and $\left.95{ }^{\circ} \mathrm{C}\right)$ and the feeding moisture content $(18 \%$ and $25 \%)$. Extrusion conditions were the temperature profiles of the extruder with values of $20,30,60{ }^{\circ} \mathrm{C}$ and $20,30,95{ }^{\circ} \mathrm{C}$, for the feeding, intermediate and output chambers respectively; screw velocity of $130 \mathrm{rpm}$, feeding rate of $7 \mathrm{~g} / \mathrm{s}$ and one die of $3 \mathrm{~mm}$ diameter. The extruded material was dried at $50^{\circ} \mathrm{C}$ for approximately $2 \mathrm{~h}$, disintegrated $(160 \mathrm{UPZ}$ fine impact mill, Hosokawa-Alpine, Germany) and sieved (Tyler sieves). The fraction with a size below $0.833 \mathrm{~mm}$ was chosen for future analyses. Water absorption index (WAI) and water solubility index (WSI) of the extruded flours were determined at $30{ }^{\circ} \mathrm{C}$ according to Anderson et al. (1970). Extruded flour suspension $\left(10 \% \mathrm{w} / \mathrm{w}\right.$, wet basis) was heated in test tubes at $30^{\circ} \mathrm{C}$ for $30 \mathrm{~min}$. Afterwards, the sample was centrifuged at $3000 \times \mathrm{g}$ for $10 \mathrm{~min}$. The precipitate was weighed, and its mass related to the mass of dry sample was expressed as water absorption index (WAI). The quantity of soluble material (water solubility index, WSI) was obtained by drying the supernatant at $100^{\circ} \mathrm{C}$ and related to the mass of dry sample. ANOVA and the significance of the difference between means was determined by Tukey test $(p<0.05)$ with InfoStat statistics software (Infostat version 2014, Argentina). All measurements were performed in triplicate.

\subsection{Bread baking}

Table 1 shows the materials used on the elaboration of gluten-free bread. Lactic acid was used in two concentrations $(0.2 \%$ and $1 \%)$, whereas the other compounds were kept constant. Dry materials were mixed together whereas yeast was previously dissolved and added together with lactic acid to the dry mixture. Afterwards, the necessary amount of water (water amount varied between $120 \%$ and $195 \%$ ) was added to the mixture to obtain a material with a fixed consistence (material flows a distance of $18 \mathrm{~cm}$ in $30 \mathrm{~s}$ ), which was measured with a Bostwick consistometer (Bourne, 1982). The mixture was then stirred with a kitchen stirrer (KitchenAid KM25G0X, U.S.A.) for two min at $120 \mathrm{rpm}$ followed for one min at $170 \mathrm{rpm}$. The stirred material (approx. $150 \mathrm{~g}$ ) was transferred to four baking containers, $12 \times 8 \times 8 \mathrm{~cm}$, (Instituto Ecuatoriano de Normalización, 1980) and fermented at $35^{\circ} \mathrm{C}, 80 \%$ moisture content in a fermentation chamber (Overena S.A., Mexico) for $60 \mathrm{~min}$. The fermented material was cooked in a convection oven (Rational SelfCookingCenter ${ }^{\circledR}$, Landsberg am Lech, Germany) at $180{ }^{\circ} \mathrm{C}, 60 \%$ moisture content for $40 \mathrm{~min}$. After baking, bread was cool down, placed in plastic bags and stored at room temperature (approx. $15^{\circ} \mathrm{C}$ ) for $24 \mathrm{~h}$ before the analyses. 
Table 1. Ingredients for gluten-free bread elaboration. Control sample and bread based on extruded quinoa (Chenopodium quinoa Willd) flour and lactic acid.

\begin{tabular}{ccc}
\hline Ingredients $^{1}$ & Control $^{\mathbf{3}}$ & Gluten-free bread $^{\mathbf{3}}$ \\
\cline { 2 - 3 } & $\mathbf{( \% )}$ & $\mathbf{( \% )}$ \\
\hline Rice flour & 30 & 30 \\
\hline Gluten-free flour ${ }^{2}$ & 70 & - \\
\hline Extruded quinoa flour & - & 70 \\
\hline Yeast & 3 & 3 \\
\hline Salt & 1 & 1 \\
\hline Margarine & 2 & 2 \\
\hline Lactic acid & & $0.2 / 1^{4}$ \\
\hline
\end{tabular}

${ }^{1}$ Sciarini (2011). ${ }^{2}$ Gluten free flour (Bob's Red Mill Natural Foods, U.S.A.), composed of garbanzo bean flour, potato starch, whole grain white sorghum flour, tapioca flour and fava bean flour. ${ }^{3}$ Percentages based on the total flour weight. ${ }^{4}$ Either $0.2 \%$ or $1 \%$ were utilized in gluten-free bread elaboration.

Bread baking was performed three times for each treatment, obtaining four pieces of bread each time. The effect of lactic acid concentration $(0.2 \%$ and $1 \%)$ on the specific volume, firmness and crumb characteristics (average cell size and cell number per $\mathrm{mm}^{2}$ ) of baked bread was studied. A control sample based on a commercial "gluten-free" flour (Bob’s Red Mill Natural Foods, USA) was used (Table 1).

\subsection{Physical characteristics}

Specific volume was determined by measuring volume and mass of a piece of bread and applying the equation specific volume=volume/mass (Huang et al., 2008). Crumb firmness was measured with a Brookfield texturometer (Brookfield Engineering Laboratories, Inc., MA, U.S.A.). Bread pieces of $2.5 \mathrm{~cm}$ width were obtained with an electric knife and loaded to the texturometer. Compression test with a deformation of $40 \%$, a cylindrical jig of $25.4 \mathrm{~mm}$ diameter, speed of $1.67 \mathrm{~mm} / \mathrm{s}$ and a recovery time of $12 \mathrm{~s}$ was used.

The crumb characteristics were determined with a digital image analysis according to Sciarini (2011). A cross section of bread sample was scanned (Epson scanner, Epson America, Inc., Long Beach CA, U.S.A.) and a section of the scanned image analysed with an Image J 1.48f software (National Health Institute, U.S.A.). The obtained results were load and analysed by PeakFit v4 software (Jandel Scientific, San Rafael, U.S.A.). Specific volume, firmness and crumb characteristics were determined three times. Results of specific volume, firmness, average cell size and cell number per $\mathrm{mm}^{2}$ were evaluated by ANOVA and a Tukey test $(p<0.05)$.

\section{Results and discussion}

\subsection{Flour extrusion}

Raw quinoa flour showed low WAI and WSI ( $2.06 \mathrm{~g} / \mathrm{g}$ and $0.094 \mathrm{~g} / \mathrm{g}$, respectively) compared to extruded materials $(p<0.05$, Table 2). Gelatinisation of quinoa starch during extrusion may lead to higher values of WAI and WSI. ANOVA results of the extruded flours in response to extrusion temperature and feeding moisture content showed that feeding moisture was the only significant factor $(p<0.05)$. An increase of feeding moisture content led to a decrease of WAI. During extrusion, water may act as lubricant, reducing friction between extruded materials and therefore reducing starch degradation, resulting in products with a higher water absorption. Decrease of WAI due to an increase of feeding moisture was found for rice extrusion (Ding et al., 2006) and it is opposite to the reported by Silva et al. (2009) for rice extrusion in the presence of sucrose. Different results may be due to the presence of sucrose. Starch and sucrose may compete for water inhibiting starch gelatinisation (Carvalho \& Mitchell, 2001). There was no statistical difference on WSI 
among treatments (Table 2), whereas WAI varied between 3.92 and $2.91 \mathrm{~g} / \mathrm{g}(p<0.05)$. The highest WAI value corresponded to feeding moisture of $18 \%$ and temperature of extrusion of $60{ }^{\circ} \mathrm{C}$, whereas the lowest value corresponded to $25 \%$ moisture content and temperature of extrusion of $60{ }^{\circ} \mathrm{C}$. WAI was higher than $2.31 \mathrm{~g} / \mathrm{g}$ quinoa flour, reported by Rodriguez-Sandoval et al. (2012) and slightly different than that reported by Abugoch et al. (2009), which ranged from 2.3 to $4.5 \mathrm{~g} / \mathrm{g}$ quinoa flour. Differences on WAI may be due to a different thermal treatment of the flour or a different method to determine WAI.

Table 2. Average together with standard deviations of water absorption index (WAI) and water solubility index (WSI) of extruded quinoa flour in response to extrusion temperature and feeding moisture content.

\begin{tabular}{|c|c|c|c|}
\hline \multicolumn{2}{|c|}{ Extrusion conditions } & \multirow{2}{*}{$\begin{array}{l}\text { WSI } \\
(g / g)\end{array}$} & \multirow{2}{*}{$\begin{array}{c}\text { WAI }{ }^{1} \\
(g / g)\end{array}$} \\
\hline Temperature $\left({ }^{\circ} \mathrm{C}\right)$ & Feeding moisture (\%) & & \\
\hline 60 & 18 & $0.133 \pm 0.006^{\mathrm{a}}$ & $3.92 \pm 0.195^{\circ}$ \\
\hline 95 & 18 & $0.130 \pm 0.005^{\mathrm{a}}$ & $3.82 \pm 0.122^{a}$ \\
\hline 60 & 25 & $0.138 \pm 0.006^{\mathrm{a}}$ & $2.89 \pm 0.125^{b}$ \\
\hline 95 & 25 & $0.127 \pm 0.007^{\mathrm{a}}$ & $2.91 \pm 0.129^{b}$ \\
\hline \multicolumn{2}{|c|}{ Raw quinoa flour } & $0.094 \pm 0.017^{\mathrm{a}}$ & $2.06 \pm 0.468^{c}$ \\
\hline
\end{tabular}

${ }^{1}$ Different superscript in columns indicate means are significantly different $(p<0.05)$.

High values of WAI suggest that quinoa starch granules were swollen during extrusion. This may lead to a formation of flour-water mixtures of high viscosity that could avoid the escape of gas produced during fermentation and therefore contribute to the development of high-volume bread during cooking. Formation of high viscosity mixtures was evident during stirring of extruded quinoa flours in the presence of water.

\subsection{Bread baking}

In classical bread making, wheat gluten forms a three-dimensional network that retains gas bubbles during baking. In gluten-free bread the network may be formed between lactic acid and starch (Dufour et al., 1996). Results of bread specific volume (Table 3) in response to lactic acid content showed that lactic acid was a significant factor $(p<0.05)$. According to Mestres et al. (2002) lactate plasticise starch, whereas volatile derivatives of lactic acid may contribute to gas production. Temperature of extrusion and moisture content were not significant factors $(p<0.05)$. Extrusion conditions may lead to a formation of starch gel that may not be sufficient to retain gas bubbles during baking. Additionally, extrusion may lead to glucose liberation, and this may not contribute to increase the gas retention capacity of the dough affecting the specific volume (Ortolan et al., 2015). Gluten-free bread with low lactic acid content $(0.2 \%)$ and control sample were statistically similar (1.744 and $1.975 \mathrm{~cm}^{3} / \mathrm{g}$ respectively) and had higher specific volumes than bread prepared with $1 \%$ of lactic acid (Table 3, Figure 1). The use of a mixture of flours may help to improve bread quality attributes, e.g. volume, crumb, firmness, staling rate (Sciarini et al., 2010). Control sample of the present work is a flour mixture of garbanzo, potato, sorghum, tapioca and fava bean. However, lack of information of the flour mixture composition does not help to make comparison with quality attributes of gluten-free bread based on quinoa. Dias et al. (2011) found that an increased starch degradation (from breaking glycosidic linkages and increased depolymerization), from higher amount of lactic acid together with thermal treatment may affect the ability of the starch to form internal alveolar structures responsible for bread expansion. Dufour et al. (1996) showed that fermented starch with low $\mathrm{pH}$ led to a bread with low specific volume.

Clerici et al. (2009) found similar volumes (1.63 to $2.25 \mathrm{~cm}^{3} / \mathrm{g}$ ) for bread based on extruded rice flour containing lactic acid. The results of the present work were lower than volumes reported by Sánchez et al. (2008) for bread based on extruded rice flour without acidification $\left(3.30\right.$ to $4.33 \mathrm{~cm}^{3} / \mathrm{g}$ ) and higher than the results of quinoa flour bread without acidification, with values between $1.4 \pm 0.02 \mathrm{~cm}^{3} / \mathrm{g}$ and $1.51 \pm 0.07 \mathrm{~cm}^{3} / \mathrm{g}$ (Alvarez-Jubete et al., 2010; Hager et al., 2012). Different results may be due to the use of extruded or non-extruded flours, the addition of lactic acid, different extrusion conditions or different rice varieties. 
Volume, firmness and crumb characteristics of gluten-free bread based on extruded quinoa flour and lactic acid Murgüeytio, E., \& Santacruz, S.

Table 3. Average together with standard deviations of specific volume, firmness, cell size and cell number of gluten-free bread in response to lactic acid content.

\begin{tabular}{|c|c|c|c|c|c|}
\hline $\begin{array}{l}\text { Lactic acid } \\
\text { content } \\
(\%)\end{array}$ & $\begin{array}{c}\text { Extrusion } \\
\text { temperature }\left({ }^{\circ} \mathrm{C}\right) \\
\text { and feeding } \\
\text { moisture }(\%)\end{array}$ & $\begin{array}{c}\text { Specific } \\
\text { volume }^{1} \\
\left(\mathrm{~cm}^{3} / \mathrm{g}\right)\end{array}$ & $\begin{array}{l}\text { Firmness }^{1} \\
\text { (N) }\end{array}$ & $\begin{array}{c}\text { Cell size }^{1} \\
\left(\mathbf{m m}^{2}\right)\end{array}$ & $\begin{array}{c}\text { Cell number } \\
\left(\text { cell } / \mathbf{m m}^{2}\right)\end{array}$ \\
\hline 0.2 & $60^{\circ} \mathrm{C}, 18 \%$ & $1.773 \pm 0.085 \mathrm{a}$ & $17.78 \pm 14.4 b$ & $0.17 \pm 0.01 \mathrm{~b}$ & $1.45 \pm 0.07 b$ \\
\hline 0.2 & $60^{\circ} \mathrm{C}, 25 \%$ & $1.741 \pm 0.075 \mathrm{a}$ & $25.73 \pm 9.76 b$ & $0.12 \pm 0.03 b$ & $1.87 \pm 0.22 b$ \\
\hline 0.2 & $95^{\circ} \mathrm{C}, 18 \%$ & $1.905 \pm 0.09 \mathrm{a}$ & $17.30 \pm 14.55 b$ & $0.11 \pm 0.03 b$ & $1.75 \pm 0.16 b$ \\
\hline 0.2 & $95^{\circ} \mathrm{C}, 25 \%$ & $1.744 \pm 0.083 \mathrm{a}$ & $47.35 \pm 8.3 \mathrm{ab}$ & $0.12 \pm 0.02 b$ & $1.41 \pm 0.07 b$ \\
\hline 1.0 & $60^{\circ} \mathrm{C}, 18 \%$ & $1.693 \pm 0.043 b$ & $21.21 \pm 12.29 b$ & $0.12 \pm 0.01 b$ & $2.91 \pm 0.81 b$ \\
\hline 1.0 & $60^{\circ} \mathrm{C}, 25 \%$ & $1.557 \pm 0.047 b$ & $23.48 \pm 11.39 b$ & $0.17 \pm 0.01 b$ & $1.41 \pm 0.07 b$ \\
\hline 1.0 & $95^{\circ} \mathrm{C}, 18 \%$ & $1.633 \pm 0.059 b$ & $16.73 \pm 15.23 b$ & $0.15 \pm 0.01 \mathrm{~b}$ & $2.09 \pm 0.32 b$ \\
\hline 1.0 & $95^{\circ} \mathrm{C}, 25 \%$ & $1.512 \pm 0.066 \mathrm{~b}$ & $42.12 \pm 8.14 \mathrm{ab}$ & $0.12 \pm 0.03 b$ & $1.79 \pm 0.17 b$ \\
\hline 0 & Control & $1.975 \pm 0.036 \mathrm{a}$ & $54.38 \pm 7.72 \mathrm{a}$ & $0.10 \pm 0.04 b$ & $4.08 \pm 0.19 a$ \\
\hline
\end{tabular}

${ }^{1}$ Different superscript letters in columns indicate means are significantly different $(p<0.05)$.

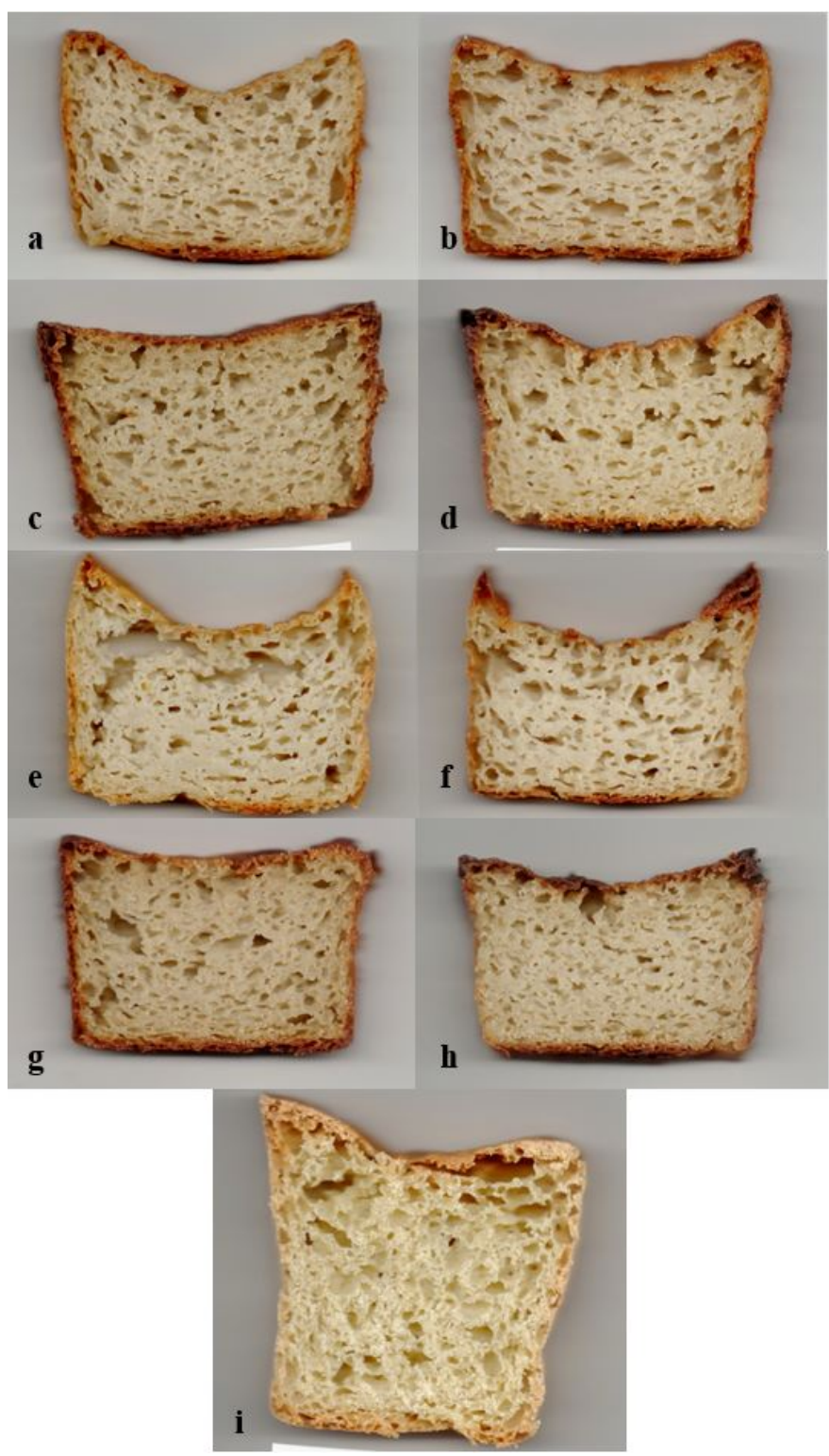

Figure 1. Cross section of bread prepared with flour extruded at different conditions of temperature $\left(60,95^{\circ} \mathrm{C}\right)$, moisture $(18,25 \%)$ and lactic acid $(0.2,1 \%)$ as follows (a) $60{ }^{\circ} \mathrm{C}, 18 \%, 0.2 \%$; (b) $60{ }^{\circ} \mathrm{C}, 18 \%, 1 \%$; (c) $60{ }^{\circ} \mathrm{C}, 25 \%, 0.2 \%$;

(d) $60{ }^{\circ} \mathrm{C}, 25 \%, 1 \%$; (e) $95{ }^{\circ} \mathrm{C}, 18 \%, 0.2 \%$; (f) $95{ }^{\circ} \mathrm{C}, 18 \%, 1 \%$; (g) $95{ }^{\circ} \mathrm{C}, 25 \%, 0.2 \%$; (h) $95{ }^{\circ} \mathrm{C}, 25 \%, 1 \%$; (i) control. 
Table 3 showed that bread firmness was not affected by the lactic acid content. There was no difference in firmness among samples, only control $(54.38 \mathrm{~N})$ and bread prepared with extruded flours at $95{ }^{\circ} \mathrm{C}, 25 \%$ feeding moisture (47.35 N and $42.12 \mathrm{~N})$, had higher firmness $(p<0.05)$. A high temperature of extrusion together with high feeding moisture may produce an extruded material with major glucose liberation. This may affect the specific volume and increase crumb firmness (Ortolan et al., 2015).

The study of crumb characteristics showed that there was no difference $(p<0.05)$ on average cell size and cell number per $\mathrm{mm}^{2}$ among treatments. There were differences on cell number per $\mathrm{mm}^{2}$ (Figure 1), with values between 1.41 and 2.92 , which were lower than control sample ( 4.08 cell number per $\mathrm{mm}^{2}$ ).

The origin and type of starch influence the microstructure of bread. The formation of a foam structure in the dough faces a formation of walls between cells, which may be affected by the starch granule size (Gan et al., 1990). Contreras-Jiménez et al. (2019) reported that quinoa starch granules are lower than $1 \mu \mathrm{m}$, therefore it may affect cell wall formation to a lower extent. Commercial gluten-free bread usually has a crumb with an irregular cell size distribution. This may be the result of a difficulty to add gas during stirring and a lack of a viscoelastic network that allows gas retention during fermentation (Sciarini, 2011).

\section{Conclusions}

Low feeding moisture during cooking-extrusion may be used to properly modify functional properties of quinoa flour (high WAI). The use of an extruded quinoa flour with low levels of lactic acid led to a gluten-free bread with a high specific volume and low firmness. A complementary study of the present work could be done by using a biological acidification and a sensory evaluation of the gluten-free bread.

\section{Acknowledgements}

To Marlon Castro who provided help during the preparation of this manuscript.

\section{References}

Abugoch, L., Castro, E., Tapia, C., Añón, M., Gajardo, P., \& Villarroel, A. (2009). Stability of quinoa flour proteins (Chenopodium quinoa Willd.) during storage. International Journal of Food Science \& Technology, 44(10), 2013-2020. http://dx.doi.org/10.1111/j.1365-2621.2009.02023.x

Ahlborn, G., Pike, O., Hendrix, S., Hess, W., \& Huber, C. (2005). Sensory, mechanical, and microscopic evaluation of staling in low-protein and gluten free breads. Cereal Chemistry, 82(3), 328-335. http://dx.doi.org/10.1094/CC-82-0328

Alvarez-Jubete, L., Auty, M., Arendt, E. K., \& Gallagher, E. (2010). Baking properties and microstructure of pseudocereal flours in gluten-free bread formulations. European Food Research and Technology, 230(3), 437-445.

http://dx.doi.org/10.1007/s00217-009-1184-z

Anderson, R., Conway, H., \& Peplinski, A. (1970). Gelatinization of corn grits by roll cooking, extrusion cooking and steaming Stärke, 4(4), 130-135. http://dx.doi.org/10.1002/star.19700220408

Blanco, C., Ronda, F., Pérez, B., \& Pando, V. (2011). Improving gluten-free bread quality by enrichment with acidic food additives. Food Chemistry, 127(3), 1204-1209. PMid:25214115. http://dx.doi.org/10.1016/j.foodchem.2011.01.127

Bold, J., \& Rostami, K. (2011). Gluten tolerance; potential challenges in treatment strategies. Gastroenterology and Hepatology from Bed To Bench, 4(2), 53-57. PMid:24834157.

Bourne, M. C. (1982). Food texture and viscosity: Concept and measurement. New York: Academic Press. Retrieved in 2019, August 6, from

http://154.68.126.6/library/Food\%20Science\%20books/batch1/Food\%20Texture\%20and\%20Viscosity,\%20Elsevier\%20(2002), \%200121190625.pdf

Carvalho, C., \& Mitchell, J. (2001). Effect of sucrose on starch conversion and glass transition of non-expanded maize and wheat extrudates. Cereal Chemistry, 78(3), 342-348. http://dx.doi.org/10.1094/CCHEM.2001.78.3.342

Celíacos del Ecuador. (2012). Celíacos del Ecuador: La enfermedad. Retrieved in 2019, August 6, from http://celiacosdelecuador.webnode.com/la-enfermedad/

Clerici, M., \& El-Dash, A. (2006). Extruder rice flour as a gluten substitute in the production of rice bread. Archivos Latinoamericanos de Nutricion, 56(3), 288-294. PMid:17249491.

Clerici, M., Arioldi, C., \& El-Dash, A. (2009). Production of acidic extruder rice flour and its influence on the qualities of gluten free bread. Lebensmittel-Wissenschaft + Technologie, 42(2), 618-623. http://dx.doi.org/10.1016/j.Iwt.2008.08.010 
Contreras-Jiménez, B., Torres-Vargas, O., \& Rodríguez-García, M. (2019). Physicochemical characterization of quinoa (Chenopodium quinoa) flour and isolated starch. Food Chemistry, 298, 124982. http://dx.doi.org/10.1016/j.foodchem.2019.124982

Defloor, I., De Geest, C., Schellekens, M., Martens, A., \& Delcour, J. (1991). Emulsifiers and/or extruded starch in the productions of breads from cassava. Cereal Chemistry, 68, 323-327. Retrieved in 2019, August 6, from https://onlinelibrary.wiley.com/journal/19433638

Dias, A. R. G., Zavareze, E. R., Elias, M. C., Helbig, E., Silva, D. O., \& Ciacco, C. F.. (2011). Pasting, expansion and textural properties of fermented cassava starch oxidised with sodium hypochlorite. Carbohydrate Polymers, 84(1), 268-275. http://dx.doi.org/10.1016/j.carbpol.2010.11.033

Ding, Q., Ainsworth, P., Plunkett, A., Tucker, G., \& Marson, H. (2006). The effect of extrusion conditions on the functional and physical properties of wheat-based expanded snacks. Journal of Food Engineering, 73(2), 142-148.

http://dx.doi.org/10.1016/j.jfoodeng.2005.01.013

Dufour, D., Larsonneur, S., Alarcón, F., Brabet, C., \& Chuzel, G. (1996). Improving the bread-making potential of cassava sour starch. In D. Dufour, G. M. O'Brien \& R. Best (Eds.), Cassava flour and starch: Progress in research and development (CIAT Publication, No. 271, pp. 133-142). Paris: Centro Internacional de Agricultura Tropical. Retrieved in 2019, August 6, from https://cgspace.cgiar.org/handle/10568/54845

Elgeti, D., Nordlohne, S., Föste, M., Besl, M., Linden, M., Heinz, V., Jekle, M., \& Becker, T. (2014). Volume and texture improvement of gluten-free bread using quinoa white flour. Journal of Cereal Science, 59(1), 41-47. http://dx.doi.org/10.1016/j.jcs.2013.10.010

Gan, Z., Angold, R., Williams, M., Ellis, P., Vaughan, J., \& Galliard, T. (1990). The microstructure and gas retention of bread dough. Journal of Cereal Science, 12(1), 15-24. http://dx.doi.org/10.1016/S0733-5210(09)80153-7

Gómez, M., \& Martínez, M. M. (2016). Changing flour functionality through physical treatments for the production of gluten -free baking goods. Journal of Cereal Science, 67, 68-74. http://dx.doi.org/10.1016/j.jcs.2015.07.009

Hager, A.-S., Wolter, A., Czerny, M., Bez, J., Zannini, E., Arendt, E. K., \& Czerny, M. (2012). Investigation of product quality, sensory profile and ultrastructure of breads made from a range of commercial gluten-free flours compared to their wheat counterparts. European Food Research and Technology, 235(2), 333-344. http://dx.doi.org/10.1007/s00217-012-1763-2

Huang, W., Kim, Y., Li, X., \& Rayas-Duarte, P. (2008). Rheofermentometer parameters and bread specific volume of frozen sweet dough influenced by ingredients and dough mixing temperatures. Journal of Cereal Science, 48(3), 639-646. http://dx.doi.org/10.1016/j.jcs.2008.02.008

Instituto Ecuatoriano de Normalización - INEN. (1980). Norma Técnica Ecuatoriana INEN 530: Harina de trigo: Ensayo de panificación. Quito: INEN.

Machado, N., Joy, S., Alvim, I., Carvalho da Morais, E., \& Andre, H. (2015). Addition of quinoa and amaranth flour in gluten-free breads: Temporal profile and instrumental analysis. Lebensmittel-Wissenschaft + Technologie, 62(2), 1011-1018. http://dx.doi.org/10.1016/j.Iwt.2015.02.029

Martínez, M., Calvino, A., Rosell, C., \& Gomez, M. (2014a). Effect of different extrusion treatments and particle size distribution on the physicochemical properties of rice flour. Food and Bioprocess Technology, 7(9), 2657-2665. http://dx.doi.org/10.1007/s11947-014-1252-7

Martínez, M., Marcos, P., \& Gomez, M. (2013). Texture development in gluten-free breads: Effect of different enzymes and extruded flour. Journal of Texture Studies, 44(6), 480-489. http://dx.doi.org/10.1111/jtxs.12037

Martínez, M., Oliete, B., Román, L., \& Gómez, M. (2014c). Influence of the addition of extruded flours on rice bread quality. Journal of Food Quality, 37(2), 83-94. http://dx.doi.org/10.1111/jfq.12071

Martínez, M., Rosell, C., \& Gomez, M. (2014b). Modification of wheat flour functionality and digestibility through different extrusion conditions. Journal of Food Engineering, 143, 74-79. http://dx.doi.org/10.1016/j.jfoodeng.2014.06.035

Mestres, C., Rouau, X., Zakhia, N., \& Brabet, C. (2002). Physicochemical properties of cassava sour starch. In D. Dufour \& G. O'Brien (Eds.), Cassava flour and starch: Progress in research and development (pp. 143-149). Cali, Colombia: Centro Internacional de Agricultura Tropical. Retrieved in 2019, August 6, from https://cgspace.cgiar.org/handle/10568/54846

Mestres, E., \& Rouau, X. (1997). Influence of natural fermentation and drying conditions on the physiochemical characteristics of cassava starch. Journal of the Science of Food and Agriculture, 74(2), 147-155. http://dx.doi.org/10.1002/(SICl)10970010(199706)74:2<147::AID-JSFA781>3.0.CO;2-J

Ortolan, F., Brites, L. T. G., Montenegro, F. M., Schmiele, M., Steel, C. J., Clerici, M. T. P. S., Almeida, E. L., \& Chang, Y. K (2015). Effect of extruded wheat flour and pre-gelatinized cassava starch on process and quality parameters of French-type bread elaborated from frozen dough. Food Research International, 76(Pt 3), 402-409. PMid:28455020. http://dx.doi.org/10.1016/j.foodres.2015.07.010

Parra, R., Anaya, J., \& Villarraga, A. (2014). Prevalencia de enfermedad celíaca en Latinoamérica: Revisión sistemática de la literatura y metaanálisis (Tesis de pregrado). Universidad Colegio Mayor de Nuestra Señora del Rosario, Bogotá.

Plata-Oviedo, M., \& Camargo, C. (1998). Effect of acid treatments and drying processes on physico-chemical and functional properties of cassava starch. Journal of the Science of Food and Agriculture, 77(1), 103-108.

http://dx.doi.org/10.1002/(SICI)1097-0010(199805)77:1<103::AID-JSFA10>3.0.CO;2-2

Repo-Carrasco, R., Espinoza, C., \& Jacobsen, E. (2003). Nutritional value and use of the andean crops quinoa (Chenopodium quinoa) and Kañiwa (Chenopodium pallidicaule). Food Reviews International, 19(1-2), 179-189. http://dx.doi.org/10.1081/FRI120018884 
Rinaldi, M., Paciulli, M., Caligiani, A., Scazzina, F., \& Chiavaro, E. (2017). Sourdough fermentation and chestnut flour in glutenfree bread: A shelf life evaluation. Food Chemistry, 224, 144-152. PMid:28159249.

http://dx.doi.org/10.1016/j.foodchem.2016.12.055

Rodriguez-Sandoval, E., Sandoval, G., \& Cortes-Rodríguez, M. (2012). Effect of quinoa and potato flours on the thermomechanical and breadmaking properties of wheat flour. Brazilian Journal of Chemical Engineering, 29(3), 503-510. http://dx.doi.org/10.1590/S0104-66322012000300007

Sánchez, H., González, R., Osella, C., Torres, R., \& De la Torre, M. (2008). Elaboración de pan sin gluten con harinas de arroz extrudidas. Food Science and Technology, 6, 109-116. Retrieved in 2019, August 6, from https://dialnet.unirioja.es/servlet/revista?codigo $=6905$

Sciarini, L. S. (2011). Estudio del efecto de diferentes aditivos sobre la calidad y la conservación de panes libres de gluten (Tesis). Universidad Nacional de la Plata, Argentina.

Sciarini, L., Ribotta, P., León, A., \& Pérez, G. (2010). Influence of gluten-free flours and their mixtures on batter properties and bread quality. Food and Bioprocess Technology, 3(4), 577-585. http://dx.doi.org/10.1007/s11947-008-0098-2

Silva, M. C., Carvalho, C. W. P., \& Andrade, C. T. (2009). The effects of water and sucrose contents on the physicochemical properties of non-directly expanded rice flour extrudates. Food Science and Technology, 29(3), 661-666. http://dx.doi.org/10.1590/S0101-20612009000300032

Susanna, S., \& Prabhasankar, P. (2013). A study on development of Gluten free pasta and its biochemical and immunological validation. Lebensmittel-Wissenschaft + Technologie, 50(2), 613-621. http://dx.doi.org/10.1016/j.Iwt.2012.07.040

Turkut, G., Cakmak, H., Kumcuoglu, S., \& Tavman, S. (2016). Effect of quinoa flour on gluten-free bread batter rheology and bread quality. Journal of Cereal Science, 69, 174-181. http://dx.doi.org/10.1016/j.jcs.2016.03.005

Villanueva, M., Pérez-Quirce, S., Collar, C., \& Ronda, F. (2018). Impact of acidification and protein fortification on rheological and thermal properties of wheat, corn, potato and tapioca starch-based gluten-free bread doughs. Lebensmittel-Wissenschaft + Technologie, 96, 446-454. http://dx.doi.org/10.1016/j.Iwt.2018.05.069 